\title{
Determination of the Pozzolanic Properties of Olotu Marine Clay and Its Potentials for Cement Production
}

\author{
Jide Muliu Akande ${ }^{1}$, Chinwuba Arum², Fola Micah Omosogbe ${ }^{3}$ \\ ${ }^{1,3}$ Department of Mining Engineering, The Federal University of Technology, Akure, Nigeria; ${ }^{2}$ Department of Civil Engineering, The \\ Federal University of Technology, Akure, Nigeria \\ Email: akandejm@yahoo.com, arumcnwchrist@yahoo.co.uk
}

Received October 12 $2^{\text {th }}, 2010$; revised December $16^{\text {th }}, 2010$; accepted December $31^{\text {st }}, 2010$.

\begin{abstract}
The physical and chemical properties of marine clay at Olotu in Ilaje local government of Ondo State, Nigeria were investigated. Some of the physical properties investigated include plasticity index, linear shrinkage and firing characteristics (firing colour, shrinkage percentage, and water absorption capacity). The physical properties were determined using X-ray diffractometry method. The chemical composition was determined using Atomic Absorption Spectroscopy (AAS) method. All tests were carried out according to procedures specified by relevant British and American Standards. It was established that the physical and chemical properties were adequate to qualify it as pozzolanic material for cement production when compared with other pozzolanic materials and measured against relevant standards. The cement produced was tested for compressive strength and setting times and the results confirmed the appropriateness of the use of the clay as a pozzolana.
\end{abstract}

Keywords: Fineness, Spectroscopy, Compressive Strength, Physical Properties, Portland Cement

\section{Introduction}

As the need for buildings and similar facilities and the requirement for improved quality of these facilities increased in developing countries, the demand for Portland cement also rose being the only cementitious product used for construction in these countries. The high cost of foreign exchange has been a major constraint in providing the needed schools, offices, communications infrastructure and other vital facilities needed in most of the African countries. There is therefore the need to search for cheaper alternatives to Portland cement.

The production and use of alternative cement dates back to the Roman days, and the remains of the great buildings constructed with it are a testimony to its usage dating back to antiquity. These alternative binding materials are known as pozzolanas. A pozzolana is a siliceous and aluminous material which reacts with calcium hydroxide in the presence of water to form compounds possessing cementitious properties at room temperature and have the ability to set under water [1]. Pozzolanas are classified as natural or artificial. Natural pozzolanas may further be divided into two main groups as:

1) Those derived from volcanic rocks in which the amorphous constituent is glass produced by fusion. These include volcanic ashes and tuffs, pumice, scoria and obsidian.

2) Those derived from rocks or earth for which the silica constituents contain Opal, either from precipitation of silica from solution or from the remains of organisms. Examples of these are diatomaceous earths, cherts, opaline silica, and lava containing substantial amounts of glassy component and clay which has been naturally calcined by heat from flowing lava. In Africa, some of the known sources of natural pozzolanas of volcanic origins may be found in Cameroon, Cape Verde, Burundi, Ethiopia, Tanzania, Kenya, Rwanda and Algeria.

Artificial Pozzolanas may be divided into two groups: those of organic and those of inorganic origin. The most important artificial pozzolanas of inorganic origin are obtained from calcined clays and shales, calcined bauxite, calcined bauxite-waste, calcined spent oil, calcined moler, calcined gaize "fly ash" (pulverized fuel coal) and brick powder (surkhi). Kaolinite is the mineral name for an economic clay commonly called kaoline. It is a group of clay minerals that consists of kaolinite, dickie, nitrite, anauxite, halloysite and endellite. They are secondary 
minerals formed by weathering hydrothermal alteration or wall rock alterations of highly feldspathic rocks whose compositions are only slightly different from each other, especially in the stacking arrangement of their structures [2]. The sources of artificial pozzolanas of organic origin are ashes of rice husk, coffee hulls, coconut shells, sugar cane bagasses and palm-nut shells and fibers. Investigations into the use of cocoa pod for pozzolana production have not been concluded. Of these pozzolanas of organic origin, rice husk ash has been well investigated and documented [3]. This research is aimed at determining the properties of Olotu marine clay in order to verify its suitability as a pozzolana for the production of cement.

\section{Materials and Method}

\subsection{Materials}

The marine clay and periwinkle shell samples used in this study were collected from Olotu, a town in Ilaje local government, south western part of Ondo state, Nigeria. Other materials include locally fabricated laboratory size electric furnace for calcining the marine clay and periwinkle shell, a thermocouple which automatically controls the heating and cooling of the furnace, a laboratory size ball mill for milling the calcined materials and a set of laboratory sieves. Other equipment used included the Vicat apparatus for testing the setting time of cement and a crushing machine for determining the compressive strength of moulded cubes.

\subsection{Method}

\subsubsection{Production Procedure}

The samples of Olotu marine clay were moulded into balls of about $30 \mathrm{~mm}$ in diameter and dried in the sun to reduce the moisture content. At a temperature of $700^{\circ} \mathrm{C}$, the dried clay was calcined in the electrically heated furnace for about 3 hours. This temperature was maintained with the aid of a thermocouple and a suction fan at the exhaust. After 24 hours the calcined clay was pulverized and milled in the ball mill and later sieved using a set of laboratory sieves with sieve shaker to fines of $1.18 \mathrm{~mm}$.

The periwinkle shell was heated at $750^{\circ} \mathrm{C}$ for 1.75 hours in the furnace with the temperature controlled using the thermocouple, and the carbon dioxide gas $\left(\mathrm{CO}_{2}\right)$ pressure reduced or controlled by the suction fan at the exhaust. The fan sucked out the emitted $\mathrm{CO}_{2}$ by the shell, reducing the pressure in the furnace and thereby avoiding re-carbonation of the quicklime produced. The discharged quicklime was slaked by manually sprinkling some quantity of water (55 liters per $200 \mathrm{~kg}$ i.e., $27.5 \%$ of shell weight) on it. The slightly moist and hot slaked lime was left to dry out and cool for 24 hours, after which it was pulverized and milled in the ball mill and then sieved through $1.18 \mathrm{~mm}$ mesh.

The processed materials were batched by weight in the ratios $3: 1$ and $2: 1$ corresponding to three pozzolana to one lime and two pozzolana to one lime [4,5]. Regrinding of the mix was done in the ball mill to produce fines of 125-106 microns (120-150 mesh) after sieving. The Lime-Pozzolana Cement (LPC) was bagged in polyethylene-lined bag and ready for use.

\subsubsection{Tests for Setting Time}

The Vicat apparatus was used for the purpose of determining the setting time and standard consistency of the lime-pozzolana cement in accordance with the provisions of [6], with a needle diameter $1.30 \mathrm{~mm}$ and load $300 \mathrm{~g}$. The needle was released at the surface of the hydrated cement paste at intervals until it penetrated only to a point $5 \mathrm{~mm} \pm 1 \mathrm{~mm}$ from the bottom of the mould. When the paste attained this degree of stiffness, it was said to have reached initial set. A second needle, similar to the first but with an attached concentric ring was then used to determine final setting time. This was reached when the needle made an impression on the surface of the paste but did not penetrate the $0.5 \mathrm{~mm}$ necessary for the ring to mark the surface.

\subsubsection{Compressive Strength Tests}

\subsubsection{Moulding and Testing of Cubes}

Various cubes were made using $150 \mathrm{~mm}$ cube moulds. Table 1 shows the mix proportions of the mortar used for the cubes (A to C) cast from different cements as proportions by weight of Cement: Sand: Water. A constant volume of water was used [4].

Cubes A1 and A2 were produced from Ordinary Portland Cement (OPC) and served as control for B1, B2 and $\mathrm{C}$ produced from Lime-Pozzolana Cement (LPC). The compressive strengths of the cubes were obtained at ages 7, 14, 21 and 28 days. The densities of the cubes were calculated when wet and when dry.

\section{Results and Discussion.}

\subsection{Results}

\subsubsection{Physical Properties}

The firing characteristics of Olotu clay are shown in Ta-

Table 1. Mortar mix proportions for different cements.

\begin{tabular}{cccc}
\hline Cube mark & \multicolumn{3}{c}{ Composition } \\
\hline A1 & OPC & Sand & Water \\
A2 & 1 & 3 & 0.6 \\
B1.1 & 1 & 2 & 0.6 \\
B1.2 & LPC & Sand & Water \\
B2.1 & 1 & 3 & 0.6 \\
B2.2 & 1 & 2 & 0.6 \\
& 1 & 3 & 0.6 \\
C & 1 & 2 & 0.6 \\
& $($ OPC:LPC $)$ & Sand & Water \\
& $(7: 3)$ & & 0.6 \\
\hline
\end{tabular}


ble 2 while the results of its essential geotechnical index properties are presented in Table 3.

\subsubsection{Chemical Composition}

The result of the analysis of Olotu marine clay for chemical composition is shown in Table 4 while the chemical composition of the periwinkle shells is shown in Table 5.

\subsubsection{Setting Time}

The results of the tests for the setting times of the various cements are presented in Table 6.

\subsubsection{Compressive Strength}

The result of the compressive strengths of mortar cubes cast from the various cements, including their weights and densities, is presented in Table 7.

\subsection{Discussion of Results}

\subsubsection{Firing Characteristics}

The moist samples were dark and light to dark grey in colour but later exhibited colour change when fired. Two groups of fired colours were obtained: reddish brown/ pinkish and buff colours. These colours showed dependence on the amount of iron and titanium (as pigment) oxides present. The clays with iron oxides between 2-3 percent give reddish brown and pink colour (Table 2). This result is somewhat similar to those obtained by Ogbukagu [7] for argillacious clays of Suthern Nigerian sedimentary basin. It has been established [8] that clays with iron oxide exceeding 2-3 percent usually give pinkish and/or reddish brown colour upon firing whereas,

Table 2. Firing characteristics of Olotu marine clay.

\begin{tabular}{ccccc}
\hline $\begin{array}{c}\text { Sample } \\
\text { No. }\end{array}$ & $\begin{array}{c}\text { Moist } \\
\text { colour }\end{array}$ & $\begin{array}{c}\text { Firing } \\
\text { colour }\end{array}$ & $\begin{array}{c}\text { Shrinkage } \\
\mathbf{( \% )}\end{array}$ & $\begin{array}{c}\text { Water } \\
\text { absorption } \\
\mathbf{( \% )}\end{array}$ \\
\hline $\mathbf{1 .}$ & DG & RB & 17.23 & 13.50 \\
2. & LG & CBU & 14.50 & 11.40 \\
3. & DG & P & 13.63 & 13.34 \\
4. & DG & RB & 13.42 & 13.22 \\
$\mathbf{5 .}$ & G & C & 12.57 & 12.58 \\
\hline
\end{tabular}

Table 3. Some geotechnical index properties of Olotu marine clay.

\begin{tabular}{cccccc}
\hline $\begin{array}{c}\text { Sample } \\
\text { No. }\end{array}$ & $\begin{array}{c}\text { Clay }+ \\
\text { Silt (\%) }\end{array}$ & $\begin{array}{c}\text { Sand } \\
\mathbf{( \% )}\end{array}$ & $\begin{array}{c}\text { Plastic } \\
\text { Limit } \\
\mathbf{( \% )}\end{array}$ & $\begin{array}{c}\text { Plasticity } \\
\text { Index }\end{array}$ & $\begin{array}{c}\text { Linear } \\
\text { Shrinkage (\%) }\end{array}$ \\
\hline 1. & 88.0 & 12.0 & 64.7 & 43.7 & 13.50 \\
2. & 82.0 & 18.0 & 52.5 & 35.4 & 11.38 \\
3. & 95.0 & 15.0 & 36.7 & 36.5 & 11.42 \\
4. & 86.0 & 14.0 & 58.7 & 39.3 & 11.60 \\
5. & 90.0 & 10.0 & 68.3 & 46.3 & 12.30 \\
\hline
\end{tabular}

Table 4. Chemical composition of Olotu marine clay (\%).

\begin{tabular}{cccccccccc}
\hline Sample & $\mathrm{SiO}_{2}$ & $\mathrm{Al}_{2} \mathrm{O}$ & $\mathrm{Fe}_{2} \mathrm{O}_{3}$ & $\mathrm{TiO}_{2}$ & $\mathrm{MgO}$ & $\mathrm{CaO}$ & $\mathrm{K}_{2} \mathrm{O}$ & $\mathrm{NaO}$ & $\mathrm{LOI}$ \\
\hline $\mathrm{BH} 1$ & 52.30 & 12.71 & 3.44 & 1.02 & 0.38 & 2.55 & 0.30 & 0.51 & 26.80 \\
$\mathrm{BH} 2$ & 48.73 & 18.52 & 3.46 & 0.86 & 0.51 & 2.42 & 0.41 & 0.47 & 24.59 \\
$\mathrm{BH} 3$ & 54.20 & 24.02 & 2.55 & 1.05 & 0.22 & 1.97 & 0.47 & 0.64 & 14.88 \\
$\mathrm{BH} 4$ & 51.40 & 23.65 & 2.85 & 1.20 & 0.40 & 2.51 & 0.38 & 0.52 & 17.09 \\
$\mathrm{BH} 5$ & 45.66 & 22.62 & 3.85 & 1.10 & 0.31 & 2.35 & 0.43 & 0.46 & 23.22 \\
\hline
\end{tabular}

Table 5. Chemical composition of periwinkle shell (\%).

\begin{tabular}{cccccccc}
\hline $\mathrm{SiO}_{2}$ & $\mathrm{AL}_{2} \mathrm{O}_{3}$ & $\mathrm{Fe}_{2} \mathrm{O}_{3}$ & $\mathrm{CaO}$ & $\mathrm{MgO}$ & $\mathrm{NaO}$ & LOI & Total \\
\hline $\mathbf{1 . 1 8}$ & 0.51 & 0.35 & 66.13 & 0.02 & 0.11 & 33.56 & 99.86 \\
\hline
\end{tabular}

Table 6. Experimentally determined setting times of different cements.

\begin{tabular}{ccc}
\hline Cube mark & IST (Hr) & MFST (Hr) \\
\hline A & 0.72 & 10.25 \\
B1 & 1.38 & 16.08 \\
B2 & 1.20 & 15.50 \\
C & 1.00 & 13.75 \\
\hline
\end{tabular}

those with lower percentage of iron oxide develop creamy, whitish or buff shades. In the present work, about two of the samples developed cracks on firing. It was observed that those samples with high content of coarser material have this property while those with high content of fine material developed no cracks on firing.

\subsubsection{Geotechnical Index Properties}

Table 3 contains the results of the geotechnical index property tests. All the clay samples are fine grained, characterized by high proportions of clay plus silt fractions, the rest of the material being considered as sand. Close examination of the sand particles revealed that they were made up of a mixture of quartz and iron grains. These were as a result of tropical weathering of rocks.

The clay is very plastic. This property reflects in the narrow range of the plasticity index (35.4-46.3), which is attributed to very low percentage of sand and significant amount of clay and silt. These two physical properties are responsible for high linear shrinkage values $(11.38$ $-13.50 \%$ ) obtained. It could be inferred that the higher the plasticity, the higher the percentage shrinkage and the higher the clay contents.

\subsubsection{Chemical and Mineralogical Composition of Olotu Marine Clay}

The clay contained some amount of lime $(\mathrm{CaO})$, alkali and magnesia oxides less than $1 \%$. The low amount of sodium oxide indicates low proportion of montmorilonite in the samples and the low amount of potassium oxide indicates low amount of illite present. 
Table 7. Compressive strength of mortar cubes.

\begin{tabular}{|c|c|c|c|c|c|c|c|}
\hline \multirow{2}{*}{$\begin{array}{l}\text { Cube } \\
\text { mark }\end{array}$} & \multirow{2}{*}{$\begin{array}{l}\text { Wet weight } \\
(\mathrm{kg})\end{array}$} & \multirow{2}{*}{$\begin{array}{l}\text { Density } \\
\left(\mathrm{kg} / \mathrm{m}^{3}\right)\end{array}$} & \multirow{2}{*}{$\begin{array}{l}\text { Dry weight } \\
(\mathrm{kg})\end{array}$} & \multirow{2}{*}{$\begin{array}{l}\text { Density } \\
\left(\mathrm{kg} / \mathrm{m}^{3}\right)\end{array}$} & \multicolumn{3}{|c|}{ Compressive strength (MPa) } \\
\hline & & & & & 7 days & 14 days & 28 days \\
\hline \multirow{3}{*}{ A1 } & 7.51 & 2225 & 6.41 & 1902 & 6.91 & 9.96 & 15.40 \\
\hline & 7.56 & 2240 & 6.42 & 1893 & 7.11 & 10.06 & 15.41 \\
\hline & 7.43 & 2201 & 6.39 & 1899 & 7.02 & 10.18 & 15.42 \\
\hline \multirow{3}{*}{ A 2} & 7.60 & 2252 & 7.23 & 2142 & 10.10 & 11.12 & 18.15 \\
\hline & 7.58 & 2245 & 7.24 & 2143 & 11.11 & 14.50 & 18.13 \\
\hline & $\begin{array}{l}7.62 \\
\mathrm{~B}^{1.1}\end{array}$ & 2258 & 7.22 & 2139 & 11.12 & 14.60 & 18.11 \\
\hline \multirow{7}{*}{ B1 } & 7.28 & 2157 & 6.84 & 2026 & 3.76 & 5.60 & 7.83 \\
\hline & 7.32 & 2168 & 6.82 & 2021 & 3.89 & 5.54 & 7.81 \\
\hline & 7.32 & 2168 & 6.86 & 2032 & 3.77 & 5.56 & 7.79 \\
\hline & $\mathrm{B}^{1.2}$ & & & & & & \\
\hline & 7.37 & 2183 & 6.94 & 2056 & 4.75 & 7.32 & 10.01 \\
\hline & 7.38 & 2186 & 6.98 & 2068 & 4.74 & 7.30 & 10.03 \\
\hline & 7.35 & 2177 & 6.95 & 2059 & 4.76 & 7.28 & 10.05 \\
\hline \multirow{8}{*}{ B2 } & $\mathrm{B}^{2.1}$ & & & & & & \\
\hline & 7.40 & 2192 & 6.96 & 2062 & 2.99 & 2.90 & 4.60 \\
\hline & 7.42 & 2198 & 6.98 & 2063 & 2.13 & 3.01 & 4.63 \\
\hline & 7.38 & 2186 & 6.94 & 2056 & 2.17 & 3.03 & 4.66 \\
\hline & $\mathrm{B}^{2.2}$ & & & & & & \\
\hline & 7.52 & 2228 & 6.98 & 2068 & 2.91 & 4.40 & 5.66 \\
\hline & 7.53 & 2281 & 7.10 & 2077 & 2.96 & 4.20 & 5.64 \\
\hline & 7.51 & 2225 & 6.95 & 2059 & 2.92 & 4.02 & 5.62 \\
\hline \multirow{3}{*}{$\mathrm{C}$} & 7.45 & 2207 & 7.02 & 2080 & 5.33 & 8.55 & 12.38 \\
\hline & 7.58 & 2216 & 7.04 & 2085 & 5.31 & 8.50 & 12.40 \\
\hline & 7.42 & 2198 & 7.03 & 2082 & 5.24 & 8.45 & 12.44 \\
\hline
\end{tabular}

The X-Ray Diffraction (XRD) anaysis showed that kaoline was the main clay mineral present in the sample. It is recognized on the diffractograms at $2 \theta$ values of 26.60, 50.12, 20.13 and 68.08 (Figure 1). Quartz (60.03, $54.05,36.30$ and 12.40 ) is the principal non-clay mineral in all the samples. The illite mineral appears at values $70.50,72.50$ and 76.80 . The kaolinite and quartz peaks are the most prominent on the diffractogram. Kaolinite is the dominant clay mineral in the deposit and quartz is the main subsidiary non-clay mineral detected from the XRD trace.

\subsubsection{Chemical Composition of Periwinkle Shell}

Analysis of periwinkle shells presented in Table $\mathbf{5}$ shows a large percentage of $\mathrm{CaO}$, which is a common characteristic of shells. Its low magnesia content is a proof that it possesses the general properties of calcium limes [9]. This is one of the criteria that qualified it as source of lime in this research work.

\subsubsection{Setting Time of LPC}

From the results of the tests for setting time shown in Table 6, the times for LPC (B1) are longer than that of Portland cement but still within the limit specified by BS 12 [10]. The longer times of the LPC are due to low fineness of the materials compared with Portland cement. The water content of the paste is another factor that affects the setting time of cements. The higher the water content of the paste, the longer it will take for the hydration product to form a structure with the chosen resis- tance to penetration. Water to cement ratio of 0.60 tested in Britain and favored in other European countries and in USA is adopted in this work: Table $1[4,10]$. The factors put together contributed to the differences shown in Table 6. As shown in the table, the initial setting time of $\mathrm{C}$ is low compared to those of B1 and B2. This is as a result of the presence of OPC which boosted the hydration process.

\subsubsection{Compressive Strength of LPC}

Table 7 shows a high positive correlation between the density of a cube and its compressive strength. It shows that the higher the density the higher the compressive strength of the cube.

The major factor responsible for variations in strength between group $\mathrm{A}$ and $\mathrm{B}$ is the variation in silicate content. Group B1 has higher strength than B2 because the cement has the proportion of silicates needed for good strength and so preferred to B2. Figure 2 illustrates the variation in strengths of cubes made from different cements, with B1 having a steady increase in strength after the seventh day.

\section{Conclusions}

From the results of this work the following conclusions are apt.

1) The clay exhibits properties that qualify it as pozzolanic material for cement production, having $66.5 \%$ of the oxides of silicon, aluminium and iron and $2.36 \%$ of 


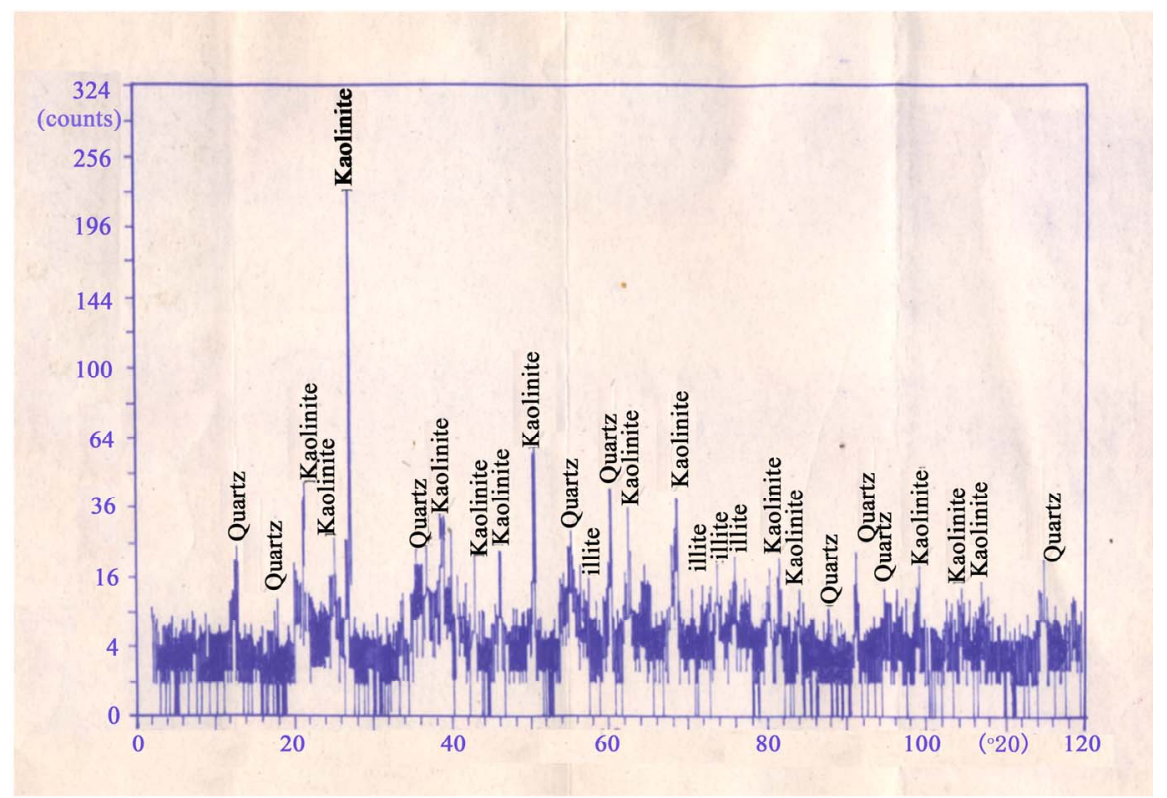

Figure 1. X-ray diffraction pattern of Olotu marine clay.

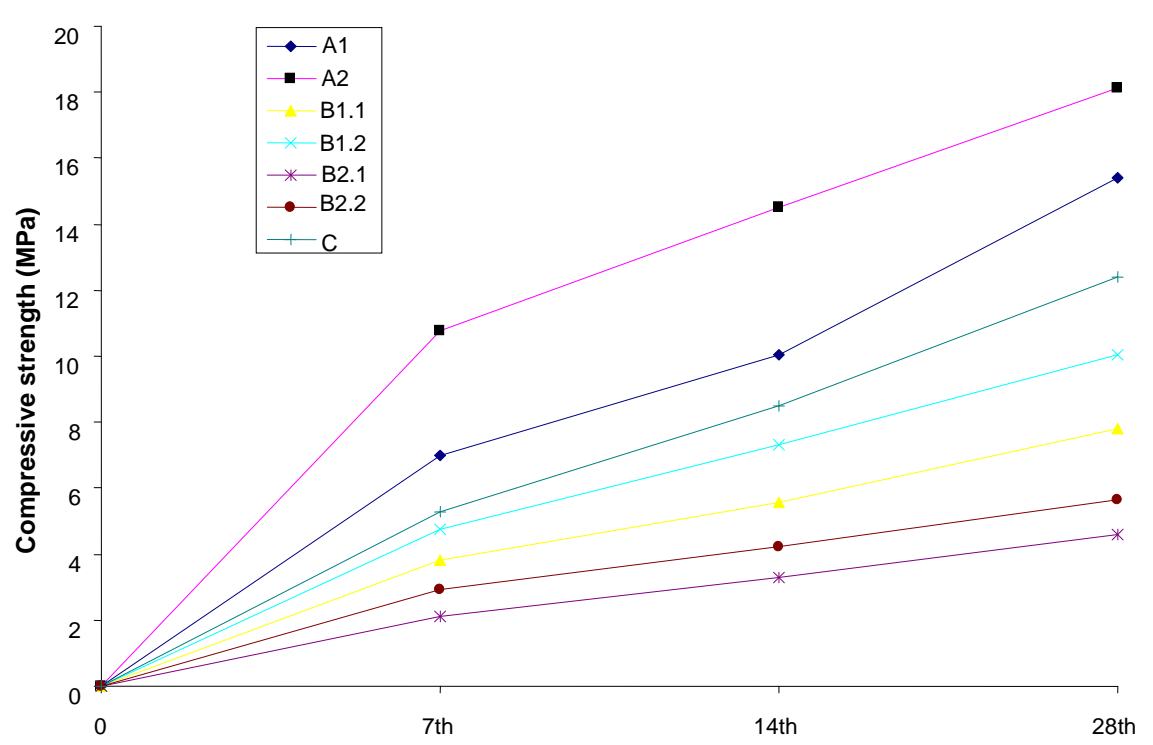

Figure 2. Relationship between the age of mortar and its compressive strength, for different cements.

calcium oxide in line with the recommendations of the American Society for Testing and Materials (ASTM).

2) The delay in the setting times of the lime pozzolana cements is as a result of its low fineness compared with Portland cement.

\section{REFERENCES}

[1] Annon, "Pozzolana," 2010. http://en.wikipedia.org/wiki/ Pozzolana.

[2] J. M. Akande and A. D. Bida, "Concentration Methods of Major Portar Kaoline Deposit, Plateau State", Interna- tional Journal in Engineering, Science and Technology, Vol. 3, No. 1, 2006, pp. 192-199.

[3] A. A. Hammond, "Manufacture and Use of Lime and Alternative Cements in Africa," In: N. Hill, F. Holmes and D. Mather, Eds., Lime and Other Alternative Cements, Intermediate Technology Publication Ltd., London, 1992, pp. 35-45.

[4] W. B. Balu, "Research on Development of Alternative Cements Based on Lime Pozzolanas in Uganda for Use in Rural Housing," In: N. Hill, F. Holmer and D. Mather, Eds., Lime and Other Alternative Cements, Intermediate Technology Publication Ltd., London, 1992, pp. 105-118. 
[5] P. H. Nalk, "KVIC Technology in the Production of Lime and Alternative Cements in India," In: N. Hill, F. Holmes and D. Mather, Eds., Lime and Other Alternative Cements, Intermediate Technology Publication Ltd., London, 1992, pp. 180-186.

[6] BS 1881: “Testing Concrete, Part 131: Methods for Testing Cement in a Reference Concrete," England.

[7] I. N. Ogbukagu, "Properties and Beneficiation of Argillaceous Rocks of Southern Nigerian Sedimentary Basin," Journal of Mining and Geology, Vol. 19, No. 2, 1982, pp. 43-51.

\section{Notation}

$\begin{array}{ll}\text { OPC } & \text { Ordinary Portland Cement } \\ \text { LPC } & \text { Lime Pozzolana Cement } \\ \text { C } & \text { Cream } \\ \text { CBU } & \text { Cream Buff } \\ \text { DG } & \text { Dark Grey } \\ \text { G } & \text { Grey }\end{array}$

[8] G. Enuvie, J. O. Akpokodje and B. N. Olorunfemi, "The Composition and Physical Properties of Some Ceramic and Pottery Clays of South Eastern Nigeria," Journal of Mining and Geology, Vol. 27, No. 1, 1991, pp. 1-6.

[9] J. W. Herath, "Lime industry in Sri Lanka," In: N. Hill, F. Holmes and D. Mather, Eds., Lime and Other Alternative Cements, Intermediate Technology Publication Ltd., London, 1992, pp. 65-68.

[10] G. C. Bye, "Portland Cement Composition, Production and Properties," A. Wheaton and Co. Ltd., Exeter, 1983.

$\begin{array}{ll}\text { LG } & \text { Light Grey } \\ \mathrm{P} & \text { Pinkish } \\ \mathrm{RB} & \text { Reddish Brown } \\ \text { IST } & \text { Initial Setting Time } \\ \text { MFST } & \text { Maximum Final Setting Time }\end{array}$

